\title{
STUDI KASUS SISWA YANG BEREKONOMI TINGGI TERHADAP KEMAUAN BELAJAR PADA SISWA KELAS X SMK KARYA BAKTI KECAMATAN SELESAI TAHUN PELAJARAN 2017/2018
}

\author{
Tumiyem, Tika Sari Devi Br Ginting \\ STKIP Budidaya Binjai
}

\begin{abstract}
Abstrak
Adapun tujuan dalam penelitian ini adalah untuk mengetahui studi kasus siswa yang berekonomi tinggi terhadap kemauan belajar pada siswa kelas X SMK Karya Bakti Kecamatan Selesai tahun pelajaran 2017/2018. Populasi dalam penelitian ini adalah keseluruhan siswa, sedangkan yang menjadi sampel yaitu key informan sebanyak 3 orang siswa.Berdasarkan hasil penelitian diketahui bahwa tingkat status ekonomi tinggi di SMK Karya Bakti dari 32 siswa hanya 3 siswa yang tergolong berekonomi tinggi. Tingginya ekonomi dapatr dilihat dari penghasilan yang diperoleh orang tua setiap bulannya. Siswa yang berekonomi tinggi memiliki kemauan belajar yang cukup baik dalam belajarnya. Hal ini dapat disebabkan oleh faktor ekonomi yang menunjang kegiatan siswa dalam belajarnya. Status ekonomi siswa memiliki pengaruh terhadap kemauan belajar siswa dalam belajarnya di sekolah. Hal ini dapat dilhat dari pemenuhan kebutuhan siswa dalam belajarnya. Semakin baik pemenuhan kebutuhannya semakin baik pula belajarnya.

Kata Kunci :siswa yang berekonomi tinggi, kemauan belajar
\end{abstract}

\section{PENDAHULUAN}

Kegiatan belajar mengajar merupakan kegiatan pendidikan, dalam kegiatan ini siswa diharapkan aktif melakukan berbagai aktivitas belajar sebagai upaya mendapatkan informasi dan pengetahuan mengenai hal-hal yang belum diketahui yang dapat diperoleh siswa dari guru dalam proses pembelajaran. Proses pembelajaran tidak terjadi secara otomatis, tetapi dilakukan bersama-sama antara guru dan siswa sehingga siswa mendapatkan ilmu pengetahuan secara sempurna dan baik yang pada akhirnya siswa akan meraih hasil belajar yang optimal.

Menurut Sardiman "Pendidikan dan pengajaran adalah salah satu usaha yang bersifat sadar tujuan yang dengan sistematis terarah pada perubahan tingkah laku menuju kedewasaan anak didik". Sedangkan menurut Dimyati dan Mujiyono "Pendidikan merupakan suatu tindakan yang memungkinkan terjadinya belajar dan perkembangan". Dengan jalan pendidikan, diharapkan mampu melahirkan generasi masa depan atau sumber daya manusia yang berkualitas.

Kegiatan belajar mengajar dilakukan secara terencana dan menyentuh aspek psikis siswa, sehingga tumbuh motivasi dan minat bagi siswa untuk melakukan aktivitas belajar dan meraih prestasi belajar yang tinggi, sebab prestasi belajar yang tinggi hanya akan diperoleh bilamana dilakukan aktivitas belajar yang serius dan bersungguhsungguh.Imam Barnadib"Dengan sendirinya semua perilaku pendidikan, yaitu pendidik serta peserta didik mengalami peningkatan secara keseluruhan". Sebagai konsekuensinya peserta didik yang terlibat dalam proses pendidikan mengalami peningkatan baik pengetahuannya maupun keterampilanya.

Salah satu prinsip dalam melaksanakan pendidikan adalah peserta didik secara aktif mengambil bagian dalam kegiatan pendidikan yang dilaksanakan. Untuk dapat terlaksananya suatu kegiatan harus ada dorongan untuk melaksanakanya. Dengan kata lain, harus ada motivasi atau kemauan. Motivasi atau kemauan yang kuat dalam proses pendidikan menjadikan peserta didik lebih aktif dan berpartisipasi dalam mengikuti kegiatan belajar mengajar. Menurut Sardiman "Motivasi adalah perubahan energi dalam diri seseorang yang ditandai dengan munculnya "Feeling" dan didahului dengan tanggapan terhadap adanya tujuan". Oleh karena itu, keberhasilan siswa dalam proses pendidikan tidak terlepas darimotivasi/kemauan belajar yang dimiliki siswa itu sendiri, 


\section{Jurnal Serunai Ilmu Pendidikan \\ Vol.4, No.1, Desember 2018 \\ e-ISSN 2621-2676}

karena kemauan merupakan suatu dorongan yang kuat dalam belajar sehingga siswa benar-benar dan bersungguh-sungguh dalam menerima ilmu pengetahuan dalam setiap proses belajar mengajar.

Adanya kegiatan belajar mengajar yang dilakukan oleh guru di sekolah, serta dukungan yang diberikan orang tua dan keluarga terhadap kegiatan belajar siswa, tidak lain adalah untuk menumbuh kembangkan kreativitas siswa supaya siswa memiliki pengetahuan, keterampilan, berwawasan dan yang paling penting adalah untuk meningkatkan hasil belajar siswa.

Prestasi belajar siswa terutama dalam pendidikan agama Islam tidak terlepas adanya upaya dan peranan guru agama dalam mengelola proses belajar mengajar dari segala hal yang berkaitan dengan materi, metode, penguasaan guru terhadap metode dan materi sekaligus upaya untuk menciptakan gairah belajar siswa sehingga kemauan untuk belajar terbina dengan baik dan sungguh-sungguh.

Siswa yang belajar dengan baik dan sungguh-sungguh tidak terlepas dari dorongan dari luar dirinya yaitu guru, orang tua, fasilitas dan sebagainya. Namun kemauan belajar juga muncul dari dalam diri siswa. Oleh karena itu seorang guru sebagai tenaga pendidik dan pengajar harus mampu membangkitkan kemauan belajar siswa agar siswa benar-benar berhasil dalam pendidikan sehingga menjadi siswa yang berkualitas, kreatif, aktif dan mandiri.

Belajar adalah sebuah proses perubahan didalam kepribadian manusia dan perubahan tersebut ditampakan dalam bentuk peningkatan kualitas dan kuanitas tingkah laku seperti peningkatan kecakapan, pegetahuan, sikap, kebiasaan, pemahaman, keterampilan, daya pikir, dan kemampuan-kemampuan yang lain.Belajar merupakan proses dasar berkembang hidup manusia. Dengan belajar, manusia melakuka perubahanperubahan kualitatif individu sehinggah tingkah lakunya berkembang. Belajar adalah setiap perubahan yang relatif menetap dalam tingah laku, yang terjadi sebagai suatu hasil dari latihan atau pengalaman.Berikut ini adalah pengertian dan definisi belajar menurut para ahli: Ernest H. Hilgard (dalam S. Nasution) mengatakan bahwa "Belajar adalah dapat melakukan sesuatu yang dilakukan sebelum belajar atau bila kelakuan berubah sehinga lain caranya menghadapi sesuatu situasi dari pada sebelum itu". Oemar Hamalik mengatakan bahwa : "Belajar adalah bentuk perubahan dalam diri sendiri seorang yang dinyatakan dalam cara-cara berperilaku yang baru berkat pengalaman dari latihan".

Segala perbuatan, gerakan, tingkah laku kita adalah akibat tenaga tenaga dari dalam yang mempengaruhi kita. Dalam ilmu jiwa hal ini disebut karsa. Tujuan dari karsa adalah perwujudan atau pelaksanaan baik positif maupun negatif. Kemauan adalah karsa yang disadari kerohanian untuk mewujudkan atau melaksanakan sesuatu. Kemauan merupakan bentuk wujud terakhir dan tertinggi dari kesanggupan karsa kita. Kemauan berasal dari kata "mau" yang berarti ingin atau hasrat. Kemauan lahir dari dalam diri seseorang. Kemauan merupakan dorongan dari diri sendiri untuk melakukan sesuatu untuk memenuhi apa yang dibutuhkan dan diinginkan.

Setiap manusia mempunyai kecenderungan untuk selalu berhubunga dengan sesuatu yang dianggap dapat memberikan kesenangan. Dari perasaan senang inilah maka timbul kemauan untuk memperoleh, mengembangkan sekaligus berusaha mempertahankan sesuatu yang dianggap dapat mendatangkan kesenangan. Sehingga apa yang dibutuhkan dan diinginkan dapat terpenuhi.

Salah satu faktor yang mempengaruhi proses belajar adalah kemauan belajar. Kemauan belajar merupakan salah satu atribut soft skill yang dihasilkan dari proses belajar. Kemauan memegang peran penting dalam belajar. Adanya kemauan belajar dapat mendorong belajar, sebaliknya tidak ada kemauan dapat memperlemah belajar. Kemauan belajar dimiliki oleh setiap orang dengan kadar yang berbeda-beda dipengaruhi oleh kebiasaan berfikir, berkata, bertindak dan bersikap.

Namun kemauan belajar dapat berubah jika yang bersangkutan mau mengubahnya dengan cara berlatih membiasakan diri dengan hal-hal yang baru. Kemauan belajar timbul dari hasrat ingin tahu. Hasrat ingin tahu merupakan bekal manusia dan 
sudah ada sejak masa kanak-kanak. Seseorang akan berusaha mencari jawaban atas berbagai pertanyaan dari hasrat ingin tahunya, dan dari dorongan ingin tahu itulah seseorang akan berusaha mendapatkan pengetahuan mengenai hal yang dipertanyakannya. Hasrat ingin tahu seseorang terpuaskan apabila sudah memperoleh pengetahuan mengenai hal yang dipertanyakannya. Dan pengetahuan yang diinginkannya adalah pengetahuan yang benar.

Kemauan belajar tidak hanya bagaimana mencari pengetahuan atau informasi saja, tetapi juga belajar untuk tidak melakukan kesalahan dan memperbaiki kesalahan yang sudah pernah dilakukan. Misalnya kemarin mendapatkan nilai yang kurang memuaskan, maka besok akan berusaha dengan sungguh-sungguh untuk memperbaiki nilai menjadi lebih baik. Belajar juga bukan tanya untuk mendapatkan prestasi semata, tetapi belajar adalah sebuah bekal pengalaman untuk di masa yang akan datang. Belajar akan dilakukan terus menerus sampai akhir hayat. Karena pada dasarnya pendidikan adalah kebutuhan sepanjang hayat. Dengan kemauan belajar maka seseorang dapat mengembangkan diri hingga menjadi seorang yang profesional. Berikut faktor-faktor yang mempengaruhi kemauan belajar.

Dalam proses pembelajaran, ada beberapa faktor yang mempengaruhi kemauan belajar seseorang, akan tetapi dapat digolongkan dalam dua kategori, yaitu faktor internal dan faktor eksternal. Adapun faktor-faktor yang mempengaruhi kemauan belajar siswa yaitu:

1) Motivasi

2) Belajar

3) Bahan pelajaran dan sikap guru

4) Keluarga

5) Teman pergaulan

6) Lingkungan

7) Cita-cita

8) Bakat

9) Hobi

Dalam kamus besar Bahasa Indonesia indikator adalah Alat pemantau (sesuatu) yang dapat memberikan petunjuk/keterangan (Depdikbud, 1991). Kaitannya dengan minat siswa maka indikator adalah sebagai alat pemantau yang dapat memberikan petunjuk ke arah minat. Ada beberapa indikator siswa yang memiliki minat belajar yang tinggi hal ini dapat dikenali melalui proses belajar dikelas maupun dirumah.

1). Perasaan Senang

2). Perhatian dalam Belajar

3). Bahan Pelajaran dan Sikap Guru yang Menarik

4). Manfaat dan Fungsi Mata Pelajaran

Sebagaimana sudah dijelaskan pada bagian terdahulu bahwa belajar merupakan kegiatan yang dilakukan dengan penuh kesadaran untuk menghadapkan pada suatu perubahan ke arah yang lebih maju. Kegiatan belajar akan berjalan dengan lancar jika didukung oleh faktor-faktor yang menyebabkan seseorang yang mengalami hambatan dalam usahanya untuk memenuhi suatu gejala atau obyek yang sedang atau yang akan dipelajari jika terjadi hal yang sebaliknya, maka seseorang yang melakukan kegiatan belajar dapat dikatakan gagal dalam memahami gejala atau obyek sehingga usaha belajarnya tidak mampu membawa ke arah perubahan yang diharapkan.

Slameto mengatakan bahwa "dalam melakukan kegiatan belajar ada banyak faktor yang mempengaruhinya, namun secara mendasarkan faktor tersebut dapat dibagi dalam cakupan besar faktor ekstern dan intern". Faktor yang mempengaruhi prestasi belajar pada dasarnya dikategorikan menjadi dua bagian, yaitu faktor intern dan faktor ekstern.

Kedudukan sosial akan mempengaruhi kedudukan orang tersebut dalam kelompok sosial berbeda. Menurut Ngalim Purwanto mengemukakan bahwa "kemampuan ekonomi keluarga akan memberikan pengaruh baik langsung maupun tidak 
langsung pada pendidikan dan pekerjaan atau jabatan serta mempertimbangkan hasil yang dicapai pada pendidikan dan pekerjaan".Tingkat status sosial ekonomi dilihat atau di ukur dari pekerjaan orang tua, penghasilan dan kekayaan, tingkat pendidikan orang tua, keadaan rumah dan lokasi, pergaulan dan aktivitas sosial." W.S Winkel mengemukakan hal yang berbeda tentang status sosial ekonomi anatara keluarga kaya dan miskin yaitu: "Keadaan sosial ekonomi keluarga yang baik dapat menciptakan kondisi siswa yang menghambat dalam belajar, siswa berpikir bahwa untuk apa belajar dengan sungguhsungguh/rajin jika semua kebutuhan sudah terpenuhi. Sebaliknya siswa yang berasal dari lingkungan keluarga yang ekonominya lemah biasanya kerap jauh lebih rajin namun ada juga siswa yang merasa minder bila belajar bersama dengan anak-anak orang kaya".

Pernyataan di atas dapat dipahami karena keluarga yang status sosial ekonominya tinggi ada juga yang kurang memperhatikan pendidikan anaknya karena kesibukan atau karena adanya asumsibahwa uang adalah segala-galanya sehingga menomorduakan pendidikan sementara bagi keluarga yang status sosial ekonominya menengah ke bawah sangat mementingkan pendidikan yang baik dan memadai bagi anaknya dengan harapan agar anak mereka dapat memperbaiki kedudukan sosialnya. Walaupun status sosial ekonomi orang tua memuaskan, tetapi apabila mereka itu tidak memperhatikan pendidikan anaknya hal itu jugaakan berpengaruh terhadap perkembangan sosial anaknya. Artinya ada asumsi yang harus dipenuhi yaitu semua orang tua pasti menginginkan pendidikan anaknya baik, sehingga dia memperhatikan dan mengoptimalkan untuk pendidikan anaknya.

Walaupun status sosial ekonomi orang tua memuaskan, tetapi apabila mereka itu tidak memperhatikan pendidikan anaknya hal itu juga akan berpengaruh terhadap perkembangan sosial anaknya. Pernyataan di atas dapat dipahami karena keluarga yang status sosial ekonominya tinggi adapula yang kurang memperhatikan pendidikan anaknya karena kesibukan atau karena berasumsi bahwa uang adalah segala-galanya, sehingga menomorduakan pendidikan. Sementara ada keluarga yang status sosial ekonominya menengah ke bawah tetapi sangat mementingkan pendidikan yang baik dan memadai bagi anaknya agar mereka dapat memperbaiki kedudukan sosialnya.

Selain itu juga kondisi keluarga yang harmonis akan menimbulkan keberhasilan belajar siswa karena semua fungsi keluarga terealisasikan. Sedangkan kondisi keluarga yang kurang harmonis kurang mendukung keberhasilan belajar siswa karena salah satu fungsi keluarga kurang terealisasi. Perhatian orang tua terhadap anak memberikan pengaruh bagi kelancaran pendidikan anak di sekolah. Kebutuhan-kebutuhan anak pada keluarga yang berasal dari kelompok yang berstatus sosial ekonomi tinggi, cenderung akan diperhatikan, dibandingkan dengan anak yang berasal dari kelompok yang status sosial ekonomi keluarganya rendah.

Anak akan dengan mudah mengikuti proses belajar pada saat di sekolah, karena semua sarana dan prasarana pendukung dari proses pembelajaran dapat terpenuhi oleh orang tuanya. Sebaliknya, ketika status sosial ekonomi keluarga rendah maka anak akan mengalami kesulitan dalam mengikuti proses pembelajaran di sekolah, karena sarana dan prasarana pendukung dari proses pembelajaran tidak terpenuhi oleh orang tuanya. Kurangnya penekanan mengenaipentingnya pendidikan yang lebih tinggi, mempengaruhi motivasi belajar anak. Anak akan cenderung memiliki motivasi belajar rendah, karena semua kebutuhan untuk kepentingan belajar baik di sekolah maupun di rumah tidak terpenuhi oleh orang tuanya, sehingga anak menjadi tidak memiliki semangat dalam belajar.

Soerjono Soekanto menyatakan bahwa: "orang tua sebenarnya merupakan kunci motivasi dan keberhasilan studi anak dan remaja, tidak ada pihak lain yang akan dapat menggantikan peranan orang tua seutuhnya”. Keberhasilan orang tua dalam menunjang motivasi dan keberhasilan studi terletak pada eratnya hubungan antara orang tua dan anak dan yang terpenting bahwa suasana keluarga yang positif bagi motivasi dan keberhasilan studi adalah keadaan yang menyebabkan anak atau remaja merasa aman dan damai bila merasa di tengah keluarga tersebut. Perhatian kepada anak untuk memenuhi kebutuhan 
belajarnya merupakan langkah awal bagi orang tua agar anak memiliki hasrat untuk melakukan kegiatan belajar. Supaya anak dapat belajar dengan teratur, orang tua harus membiasakan anak untuk belajar di rumah. Sebaliknya kontribusi peranan orang tua dalam mendorong anaknya untuk belajar dapat mendorong anak untuk memenuhi tuntutan orang tua.

Adanya perhatian orang tua dalam membantu meningkatkan prestasi belajar dapat menumbuhkan hasrat anak untuk belajar. Hal ini seperti yang dikemukakan Moh. Surya bahwa "Orang tua yang senantiasa memberikan kontrol dalam kegiatan belajar anakanaknya, serta senantiasa memberikan motivasi untuk mencapai prestasi yang baik, akan menunjang terhadap prestasi belajar yang setinggi-tingginya". Selain sebagai tempat utama dan pertama dalam pemberian pendidikan, keluarga juga mengemban fungsi sebagai tempat memperoleh keahlian, pengetahuan dan keterampilan. Dalam keluargalah pertama kali anak belajar hidup dan mempertahankan kehidupannya. Ketidak berhasilan sebagian keluarga atau katakanlah lemahnya keluarga dalam mewujudkan fungsi dan perannya dalamperkembangan kualitas sumber daya manusia, merupakan permasalahan tersendiri yang melibatkan berbagai aspek seperti rendahnya tingkat pendidikan keluarga, lemahnya kemampuan ekonomi, ataupun besarnya komunitas keluarga dan lainnya. 4 golongan:

Berdasarkan penggolongannya, BPS membedakan pendapatan penduduk menjadi

1. Golongan pendapatan sangat tinggi jika pendapatannya melebihi Rp. 3.500.000,-.

2. Golongan pendapatan tinggi jika pendapatannya rata-rata Rp. 2.500 .000 samapai dengan Rp. 3.500.000.

3. Golongan pendapatan sedang jika pendapatan rata-ratanya Rp. 1.500 .000 samapai dengan Rp. 2.500.000.

4. Golongan pendapatan rendah jika pendapatan rata-ratanya Rp. Dibawah Rp. 1.500.000.

Berdasarkan pendapat di atas, maka seseorang itu dikatakan kaya jika berpenghasilan minimal Rp. 2.500.000. Selain itu indikator lain yang dapat dinyatakan bahwa seseorang itu dikategorikan kaya yaitu memiliki lahan perkebunan lebih dari 2 Hektar, memiliki mobil, dan rumah minimal tipe 64 dan keseluruhannya permanen.

Dalam kenyataannya, dalam setiap kelas belajar terdiri dari berbagai siswa yang berasal dari berbagai tingkat ekonomi, baik ekonomi lemah, sedang maupun tinggi. Salah satu indikator siswa berekonomi tinggi adalah penghasilan orang tua minimal $\mathrm{Rp}$. 2.500.000, memiliki mobil, tipe rumah 64, dan atau memiliki lahan perkebunan minimal 2 hektar. Dengan berbagai tingkat ekonomi tentu akan membawa kondisi belajar siswa yang bermacam-macam. Ada yang memiliki minat belajar yang tinggi, sedang maupun rendah.

Kemauan merupakan dorongan dari diri sendiri untuk melakukan sesuatu untuk memenuhi apa yang dibutuhkan dan diinginkan Kemauan belajar dimiliki oleh setiap orang dengan kadar yang berbeda-beda dipengaruhi oleh kebiasaan berfikir, berkata, bertindak dan bersikap. Dengan kemauan belajar maka seseorang dapat mengembangkan diri hingga menjadi seorang yang profesional.

Sesuai dengan penelitian ini yaitu tentang tingkat kemauan belajar bagi siswa yang berekonomi tinggi, maka penelitian ini hanya akan menganalisis siswa yang berasal dari ekonomi tinggi. Apakah tingkat ekonomi mempengaruhi kemauan belajar siswa atau tidak?. berikut:

Berdasarkan latar belakang masalah, maka teridentifikasi masalah sebagai

1. Keadaan siswa di sekolah menunjukan kemauan belajar di kelas masih rendah.

2. Siswa lebih cenderung menonjolkan kekayaan keluarga di lingkungan sekolah dibandingkan prestasi belajar di sekolah.

Berdasarkan masalah tersebut di atas, penulis berkeinginan untuk mengadakan penelitian tentang kondisi siswa yang berekonomi tinggi terhadap kemauan belajar siswa. 
Menganalisis sebab-sebab tinggi maupun rendahnya kemauan belajar siswa. Persoalanpersoalan ini mendorong penulis untuk menganalisisnya dan mencoba mengadakan penelitian berkenaan dengan : "Studi Kasus Siswa Yang Berekonomi Tinggi Terhadap Kemauan Belajar Pada Siswa Kelas X SMK Karya Bakti Kecamatan Selesai Tahun Pelajaran 2017/2018".

\section{METODE}

Penelitian ini dilaksanakan di SMK Karya Bakti, yang terletak di Jl. Jenderal Gatot Subroto Kecamatan Selesai Kabupaten Langkat. Adapun waktu pelaksanaan penelitian ini pada semester ganjil tahun pelajaran 2017/2018.

Jenis penelitian yang digunakan dalam penelitian ini adalah penelitian lapangan, yaitu penelitian yang mengambil data primer dari lapangan. Penelitian ini dimaksudkan unuk mempelajari secara intensif latar belakang keadaan sekarang dan interaksi suatu sosial, individu, dan masyarakat. Penelitian kuanlitatif yaltu penelitian yang memahami fenomena tentang apa yang dialami subjek peneltian, misalnya prilaku, motivasi, persepsi dan tindakan lainnya. Menurut Bogdan dan Maleong bahwa "penelian kulitatif adalah suatu prosedur penelitian yang menghasilkan data deskriptif berupa data-data berupa tulisan-tulisan atau lisan dari orang-orang pelaku yang diamati.

Subjek adalah orang-orang yang menjadi sumber informasi yang dapat memberikan data yang sesuai dengan masalah yang sedang diteliti. Untuk menentukan subjek penelitian maka dilakukan dengan teknik snowball sampling yaitu penelitian memulai dari keterangan informann pangkal yang dapat memberikan petunjuk tentang adanya indivudi atau kelompok lain yang dapat memberikan informasi lebih lengkap. Snowball sampling adalah suatu teknik pengambilan objek penelitian dengan mengadakan wawancara terhadap keseluruhan subjek yang diteliti. Dari hasil wawancara maka akan terlihat informan dan informan kunci (key informant).

Penelitian adalah seseorang yang, karena memiliki informasi (data) banyak mengenai objek yang sedang diteliti, dimintai informasi mengenai objek penelitian tersebut. Lazimnya informan atau narasumber penelitian ini ada dalam penelitian yang subjek penelitiannya berupa "kasus" (satu kesatuan unit), antara lain yang berupa lembaga atau organisasi atau institusi (pranata) sosial. Infroman dalam penelitian ini adalah keseluruhan siswa kelas X SMK Karya Bakti Kecamatan Selesai. Keseluruhan siswa akan diwawancarai sehingga akan diketahui siswa yang berekonomi tinggi.

Yang menjadi key informan adalah objek yang terindikasi sebagai siswa yang berekonomi tinggi (AW, TS, ZA). Hal ini dapat dilihat dari kodisi ekonomi orang tua, kondisi pakaian siswa dan uang saku yang diterima siswa setiap hari.

Teknik pengumpulan data yang dipergunakan dalam penelitian ini adalah wawancara dan observasi. Kemudian, teknik analisis data yang dapat digunakan dalam penelitian tindakan adalah dengan menggunakan teknik analisis kualitatif yang dikembangkan oleh Miles dan Huberman.

Selain menggunakan reduksi data peneliti juga menggunakan teknik Triangulasi sebagai teknik untuk mengecek keabsahan data. Dimana dalam pengertiannya triangulasi adalah teknik pemeriksaan keabsahan data yang memanfaatkan sesuatu yang lain dalam membandingkan hasil wawancara terhadap objek penelitian.

\section{PEMBAHASAN HASIL PENELITIAN}

Berdasarkan judul penelitian yaitu studi kasus siswa yang berekonomi tinggi terhadap kemauan belajar pada siswa kelas X SMK Karya Bakti Kecamatan Selesai tahun pelajaran 2017/2018. Maka peneliti melakukan penelitian pada tanggal 21 sampai dengan 24 september 2017. Sebelum melaksanakan penelitian terlebih dahulu peneliti melakukan teknik pengambilan sampel.

Berdasarkan teknik pengambilan sampel yaitu snowball sampling diketahui bahwa ada informan dan key informan. Infroman dalam penelitian ini adalah keseluruhan populasi yang kemudian dipersempit lagi untuk mencari siswa yang disebut key informan. 
Berdasarkan hasil wawancara dengan informan maka disimpulkan bahwa terdapat 3 siswa sebagai key informan, 3 orang tua siswa, dan seorang guru wali kelas.

\section{Hasil Penelitian}

Berdasarkan wawancara dengan keseluruhan keluarga dari ketiga siswa disimpulkan bahwa kondisi ketiga siswa benar dikategorikan keluarga berekonomi tinggi. Berdasarkan pendapat saudara (Kakak/Adik) disimpulkan bahwa ketiga anak tersebut rajin belajar di rumah.

Hasil wawancara dengan wali kelas, guru agama, guru penjas disimpulkan bahwa ketiga siswa tidak mengalami kesulitan dalam pembiayaan pendidikannya. Keempat siswa dikategorikan siswa dengan prestasi baik, hal ini ditunjukan dengan memperoleh rangking di kelasnya.Berdasarkan wawancara dengan ketiga siswa disimpulkan bahwa benar ketiga siswa berasal dari keluarga berekonomi tinggi atau kaya. Berdasarkan wawancara tersebut juga ditemukan bahwa siswa memiliki kemauan belajar yang tinggi.

Instrumen utama yang digunakan dalam penelitian ini adalah wawancara. Wawancara dilakukan pada Ayah, Ibu, Kakak, Adik, Wali Kelas, Guru Agama, dan Guru Penjas. Terlebih dahulu wawancara dilakukan pada Ayah, kemudian, Ibu, kemudian Kakak, kemudian Adik, kemudian Wali Kelas, kemudian guru agama, kemudian guru penjas lalu pada ketiga siswa.

Dari hasil wawancara disimpulkan bahwa ketiga siswa berasal dari keluarga berekonomi tinggi. Dari hasil wawancara juga diketahui bahwa kemauan belajar ketiga siswa sangatlah baik. Hal ini ditunjukan dengan ketiganya memperoleh rangking di kelasnya.

Berdasarkan hasil wawancara dan observasi ditemukan beberapa hal, yaitu tingkat status ekonomi tinggi di SMK Karya Bakti dari 32 siswa hanya 3 siswa yang tergolong berekonomi tinggi. Tingginya ekonomi dapat dilihat dari penghasilan yang diperoleh orang tua setiap bulannya.Siswa yang berekonomi tinggi memiliki kemauan belajar yang cukup baik dalam belajarnya. Hal ini dapat disebabkan oleh faktor ekonomi yang menunjang kegiatan siswa dalam belajarnya.Status ekonomi siswa memiliki pengaruh terhadap kemauan belajar siswa dalam belajarnya di sekolah. Hal ini dapat dilhat dari pemenuhan kebutuhan siswa dalam belajarnya. Semakin baik pemenuhan kebutuhannya semakin baik pula belajarnya.

Dengan membandingkan hasil wawancara Ayah, Ibu, Kakak, Adik, Wali Kelas, Guru Agama, dan Guru Penjas. Dimana hasil wawancara disimpulkan sebagai berikut:

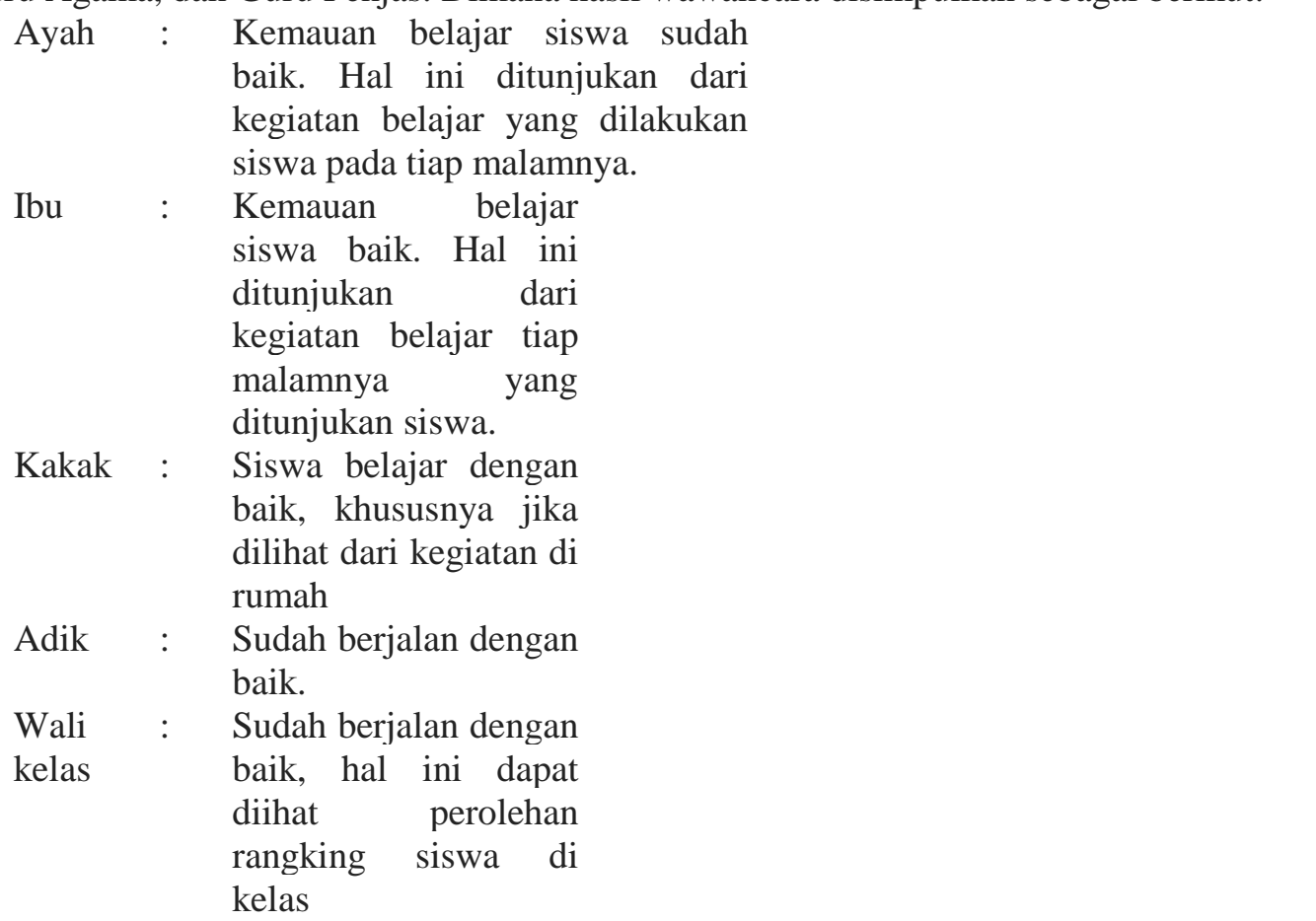




$\begin{array}{lll}\text { Guru } & : & \begin{array}{l}\text { Sudah berjalan dengan } \\ \text { agama } \\ \text { baik, hal ini dapat } \\ \text { diihat perolehan } \\ \text { rangking siswa di } \\ \text { kelas }\end{array} \\ \text { Guru } & \begin{array}{l}\text { Sudah berjalan dengan } \\ \text { Penjas } \\ \text { baik, hal ini dapat } \\ \text { diihat perolehan } \\ \text { rangking siswa di } \\ \text { kelas }\end{array}\end{array}$

Dapat dilihat bahwa jawaban keseluruhannya hapir keseluruhan sama dengan kondisi ketiga siswa. Wawancara tidak jauh berbeda dengan hasil wawancara dengan ketiga siswa. Sehingga hasil wawancara Ayah, Ibu, Kakak, Adik, Wali Kelas, Guru Agama, dan Guru Penjas sesuai dengan kondisi yang ditunjukan siswa, yang artinya sebagai informan tambahan keseluruhannya menunjukan kekosistensiannya dalam memberikan informasi

\section{SIMPULAN}

1. Tingkat status ekonomi tinggi di SMK Karya Bakti dari 32 siswa hanya 3 siswa yang tergolong berekonomi tinggi. Tingginya ekonomi dapatr dilihat dari penghasilan yang diperoleh orang tua setiap bulannya.

2. Siswa yang berekonomi tinggi memiliki kemauan belajar yang cukup baik dalam belajarnya. Hal ini dapat disebabkan oleh faktor ekonomi yang menunjang kegiatan siswa dalam belajarnya.

3. Status ekonomi siswa memiliki pengaruh terhadap kemauan belajar siswa dalam belajarnya di sekolah. Hal ini dapat dilhat dari pemenuhan kebutuhan siswa dalam belajarnya. Semakin baik pemenuhan kebutuhannya semakin baik pula belajarnya.

\section{REFERENSI}

AM, Sardiman. Interaksi dan Motivasi Belajar Mengajar. Jakarta: Rineka Cipta. 2001.

Arifin, Tatang M. Menyusun Rencanan Penelitian. Jakarta:Grafindo. 1998.

Badan Pusat Statistik. Indikator-Indikator Kondisi Ekonomi Indonesia. Jakarta: Badan Pusat Statistik. 2012.

BPS. Profil Kemiskinan di Indonesia, Maret 2009.'Berita Resmi Statistik No. 43/07/Th.XII. July 2009.

Maleong, Lexy J. Metode Penelitian Kualititaf. Bandung : Remaja Rosdakarya. 1996.

Surya, Mohammad. Psikologi Pembelajaran dan Pengajaran. Bandung: Pustaka Bani Quraisy. 2004.

Sugiono. Metode Penelitian Kuantitatif dan Kualitatif. Bandung : alfabet. 2013..

Tabrani, Rusyan. Pendekatan dalam Proses Belajar Mengajar.Bandung : PT Remaja Rosdakarya. 2009. 